\title{
Measuring the Magic: Assessment in the Special Collections and Archives Classroom
}

THOSE OF US WHO TEACH in special collections and archives settings know that instruction using original materials can spark passion, transform understanding, and change students' lives-but how can we show that those in-class experiences are meaningful in the right ways, to the right people? What are effective methods for measuring the success of our instructional work, and how do we translate the magic happening in our classrooms into a demonstration of learning impact that is useful to larger assessment endeavors?

Although assessment was already a feature of the academic library environment before the "Great Recession," the tough economic times have spurred libraries into a flurry of assessment activities, as administrators have been increasingly pressured to show demonstrable returns on investments of time and money. And though the economy now appears to be in a recovery, the intensified culture of library assessment is here to stay. As Megan Oakleaf notes in The Value of Academic Libraries, the importance of assessment in higher education today means that libraries "will continue to be compelled to participate ... and find appropriate ways to show their value."1 Sarah Pritchard, University Librarian at Northwestern University, has suggested that demonstrating this value through crafted assessment techniques is often most effective when framed in terms of alignment with institutional missions and goals. ${ }^{2}$

Education will always be a chief goal in any academic institution. According to Oakleaf and others, academic libraries are shifting into a new paradigm that integrates our services and resources into the institution's teaching and learning activities, requiring librarians to think more like educators rather than service providers. ${ }^{3}$

1. Association of College and Research Libraries, Value of Academic Libraries: A Comprehensive Research Review and Report, researched by Megan Oakleaf (Chicago: Association of College and Research Libraries, 2010), 7.

2. Sarah Pritchard, "How Special Is Your Library? Special Collections and the Value of Academic Libraries," plenary session presented at the RBMS Preconference, Baton Rouge, La., June 23, 2011.

3. Scott Bennett, "Libraries and Learning: A History of Paradigm Change," portal: Libraries and the Academy 9, no. 2 (Apr. 2009): 181-97, quoted in Association of College and Research Libraries, Value of Academic Libraries, 37.

^Please note: URLs for all websites referenced herein were valid at the time of article submission. 
Instruction, therefore, is poised as one of the more obvious and influential ways that libraries can align their work with the foundational mission of their parent academic institutions and contribute to the student learning experience. As the many imaginative case studies in the recent volume Past or Portal? Enhancing Undergraduate Learning Through Special Collections and Archives demonstrate, our departments can be ideal sites for this important contribution. ${ }^{4}$

Yet, to show how special collections and archives contribute meaningfully to instructional outcomes, we must find formal assessment techniques and strategies that can comprehensively measure our impact through both quantitative and qualitative means. While our colleagues in general library instruction and information literacy have been developing and integrating assessment techniques for years, those of us who teach in special collections and archives settings have been slower to adopt such approaches. In 2008, Magia Krause reported in her groundbreaking review of instructional practices in special collections and archives that "formal assessment of instruction ... is rarely or never part of an instruction session in the majority of repositories surveyed." The recent ARL SPEC Kit on "Special Collections Engagement" reveals an awareness among reporting institutions that assessment is useful and necessary, but also indicates frustration at finding ways to effectively measure outreach and instructional program impact beyond gate counts, repeat class bookings from pleased professors, and anecdotal feedback. ${ }^{6}$

Despite the fact that assessment offers means for improving both student learning and our teaching, special collections librarians and archivists generally have been reluctant to dive in. For every administrator's plea for the merits of assessment, there is often an equal and opposite voice from our ranks declaiming the significant effort assessment requires. Chief among the obstacles cited is time. Special collections classroom instruction is, by its nature, already a very time-consuming process. To create one session in special collections, instructor-librarians must consult with the faculty member about the learning goals, potential materials, and class logistics and do so for disciplines that are not the "home" discipline of the instructorlibrarian. The collections must be mined for appropriate class materials, and often the selections go through numerous refinements. An in-class activity or exercise is usually devised or customized if the class is to go beyond a simple "show-and-tell." Preparation of the in-class presentation and setup of materials on the day of the visit are often time-intensive tasks. Adding the preparation, administration, and

4. Eleanor Mitchell, Peggy Seiden, and Suzy Taraba, eds., Past or Portal? Enhancing Undergraduate Learning through Special Collections and Archives (Chicago: Association of College and Research Libraries, 2012).

5. Magia Krause, "Learning in the Archives: A Report on Instructional Practices," Journal of Archival Organization 6, no. 4 (2008): 257.

6. Adam Berenbak et al., SPEC Kit 317, Special Collections Engagement (Washington, D.C.: Association of Research Libraries, 2010), 14. 
evaluation of an assessment tool can present additional challenges for special collections librarians who already feel constrained by time.

Another significant challenge is that special collections librarians and archivists are called upon to teach concepts and skills across a wide spectrum. Elizabeth Yakel and Deborah Torres have described the ends of the spectrum as embracing both "archival intelligence," namely the practical skills required to locate and use special collections materials, and "artifactual literacy," which includes the ability to identify and analyze primary sources. ${ }^{7}$ A class session that focuses on archival literacy concepts addresses topics such as how to use a finding aid, how to request materials, how to find primary sources both inside and outside the department's collections, and how to use an archival collection. By contrast, a class session designed to teach artifactual intelligence concepts addresses topics such as evaluating the historical context of a document, analysis of bias and audience, and explorations of document authenticity and physicality. Of course, a single class session can include elements from both domains and therefore might require more complex approaches to assessment. As the authors of a recent blog post on assessment in special collections point out, the "assessment practices that generate the most useful results are multi-pronged in their approach."

Yet developing a toolkit of appropriate, connected assessment strategies can be challenging in its own right. Crafting such a system can easily seem too daunting for special collections librarians and archivists who are otherwise struggling to keep up with a growing demand for instructional sessions as a result of the increasing awareness and popularity of special collections and archives as resources to complement traditional curriculums.

A further obstacle to assessment is training. As Krause points out, as a community, those who teach in special collections or archives environments are largely selftrained. ${ }^{9}$ Although some may have been lucky enough to take a course on instruction as part of their library or archives master's degree programs, such courses may not have focused on methodologies specific to presenting special collections materials, much less assessment as a basic element of pedagogy. Further, when instruction duties are coupled with reference, collection development, or outreach activities, finding time for training to improve one's understanding and integration of assessment techniques is frequently difficult.

7. Elizabeth Yakel and Deborah A. Torres, "AI: Archival Intelligence and User Expertise," The American Archivist 66, no. 1 (2003): 51-78.

8. Genya O'Gara, Emily Walters, and Cate Putirskis, "Articulating Value in Special Collections: Are We Collecting Data the Matter?" In the Library with the Lead Pipe blog, September 29, 2010, available online at www.inthelibrarywiththeleadpipe.org/2010/articulating-value-in-special-collections-are-wecollecting-data-that-matter/.

9. Krause, "Learning in the Archives," 248. 
Considering the time invested in creating meaningful class sessions, it is understandable that fear might also play a role in librarians' and curators' reluctance to assess their impact. Perhaps we don't really want to know how effective (or ineffective) our instruction sessions are: the truth has the potential to hurt a little too much. The fear factor also appears when meditating on the potential use of any data generated from assessment techniques. Although the power of instruction using original primary sources can be used effectively as part of a larger argument advocating for the activities or funding of special collections and archives departments, when that data do not yield evidence of a clear return on the time investment of an instruction program, our positions and passions can be endangered. Or perhaps there is still a feeling among some of us that the informal observations we make about our own class sessions are enough, that it is already obvious that they are valuable and that formal assessment is unnecessary to prove it. However, many of us can no longer expect our stakeholders to "take our word for it," even when that word is offered by highly esteemed curators and directors. More and more we are being asked to back up informal observations of our own successes with formal assessment measures. It is our hope that pulling together examples of assessment techniques already in practice may help us to overcome these obstacles.

In this article, we examine several of the most common techniques our colleagues in information literacy instruction have used for assessing their efforts and programs. We also survey the special collections and archives literature on instructional outreach to see how similar methodologies have been used or adapted for assessing instructional outreach in special collections and archives settings and reflect on their relative merits and limitations. Finally, we explore some ideas for advancing instructional assessment in special collections and archives and applying lessons learned from assessment to our unique instructional environments.

\section{Literature Review with Discussion}

The library literature on assessment techniques for information literacy instruction (ILI) is rich, but much less has been documented within the special collections and archives literature. While the growing body of literature on instructional sessions in special collections is encouraging, assessment techniques have seldom been a part of the reported experiences. This is changing, however. ${ }^{10}$ The following section reviews several assessment models employed by the ILI community and examines how they have been adapted by special collections librarians and archivists.

10. Members of the Special Collections Teaching Strategies Member Community on ALA Connect maintain an ongoing list of articles that deal with instruction in special collections and archives. See http:// connect.ala.org/node/85063. 
Esther Grassian and Joan Kaplowitz and others describe three key levels of instructional literacy assessment. ${ }^{11}$ Reaction (affective) assessments answer the question "Did they like it?" and include tools such as surveys, questionnaires, evaluations, interviews, and focus groups. Learning (cognitive) assessments are performance-based, asking "Did they get it?" and include a range of tools for determining whether the students apply what they have learned. Common approaches include a variety of Classroom Assessment Techniques (CATs), fixed-choice tests, and out-of-class assignments. Performance (behavioral) assessments explore the application of learned skills by testing "Can they do it?" thereby comprising "authentic" assessments that ask students to demonstrate what they know or what they can do in real-life situations. Performance assessment can include assignments, citation analysis, and observational analysis. ${ }^{12}$ It should be noted that these categories and the techniques within them are somewhat fluid; for example, assignments can be used for both learning and performance assessment techniques. We have arranged our literature review based on these levels and have included a fourth section with examples of blended approaches that gather data on all three levels.

\section{Reaction Assessments: Questionnaires and Surveys}

Questionnaires, surveys, and evaluations, whether administered in written form, online, or through in-person focus groups, are useful in evaluating instruction sessions from the students' perspective. Affective surveys can ask students to gauge the level of familiarity or comfort with the material covered in class, evaluate their level of confidence after an orientation, and/or express their impressions of the class session. They are useful for capturing student self-assessments or perceptions of their own learning or experience. This feedback can be used to improve instructional design over time or adjust learning outcomes. Although this assessment technique does not measure student learning, it can be used to gather important information about student learning. It is popular among librarians because surveys and questionnaires can be relatively easy to administer. And while many are moving away from techniques that gauge satisfaction in favor of those that measure learning, this approach still carries significant merit for special collections and archives that want first of all to identify and listen to their users. Furthermore, questionnaires and surveys can be adapted to test more than satisfaction. Examples include reflec-

11. Esther Grassian and Joan Kaplowitz, Information Literacy Instruction: Theory and Practice, 2nd ed. (New York: Neal Shuman, 2009).

12. Grassian and Kaplowitz also identify a fourth level. Assessment of results measures the effect of the instruction by asking "Does it matter?" Complex, long-term results assessments require collaboration with multiple outside parties and gather information about instructional impact on the life of the learner over the long term. Although data derived from assessment efforts in special collections and archives can be contributed to such an effort, because it involves assessment at the library level and beyond, we have excluded it from this literature review. 
tive self-assessments of outcomes based on instruction or self-reporting of usage and understanding. ${ }^{13}$

In the special collections and archives arena, Shan Sutton and Lorrie Knight used a Likert scale questionnaire to give students the opportunity to appraise the most and least useful aspects of a class session, as well as to state whether they understood the difference between primary and secondary sources. Although 97 percent of the students declared that they did, the authors noted that more proof of this would be desirable and planned to modify the in-class exercise to measure this outcome more soundly. In this case, responses to the questionnaire were mainly used to modify future teaching. ${ }^{14}$ Wendy Duff and Joan Cherry employed surveys to explore the impact of archival orientation sessions on both faculty and students. ${ }^{15}$ Their questionnaires asked both parties to gauge what they liked most and least about the session, their general level of satisfaction, their confidence level at using archival collections, and their usage of primary sources for coursework. The responses showed that the orientation session did indeed have a positive impact on these aspects, but Duff and Cherry noted several limitations of the survey format, including variation in response rates and the difficulties involved in determining causal relationships between class sessions and impact. On the other hand, their inclusion of affective competencies, such as confidence level, exemplifies the potential use of this assessment tool for special collections and archives environments. Valerie Harris conducted a survey to better understand Special Collections and University Archives user satisfaction at the University of Illinois-Chicago in which she included questions related to workshops and online tutorials. She found that undergraduates were more likely than faculty to value online tutorials, while all groups surveyed expressed interest in workshops on archives and manuscripts, particularly workshops on using finding aids rather than those focused on rare books. ${ }^{16}$

The Archival Metrics Toolkit, developed by Elizabeth Yakel, Helen Tibbo, and Wendy Duff beginning in 2008, is a suite of eight standardized evaluation metrics designed to provide practical, sustainable assessment tools to the archives and special collections communities. The development of the Archival Metrics survey instruments has considerably advanced efforts to assess instructional programs

13. The ILI literature on surveys and questionnaires is vast. For more on survey use, see Association of College and Research Libraries, Value of Academic Libraries.

14. Shan Sutton and Lorrie Knight, "Beyond the Reading Room: Integrating Primary and Secondary Sources in the Library Classroom," Journal of Academic Librarianship 32, no. 3 (May 2006): 320-26.

15. Wendy M. Duff and John M. Cherry, "Archival Orientation for Undergraduate Students: An Exploratory Study of Impact," The American Archivist 71, no. 1 (2008): 499-529.

16. Valerie Harris, "How Can I Help You? Becoming User-Centered in Special Collections," Archival Issues 32, no. 2 (Nov. 2010): 71-97. 
in special collections and archives. ${ }^{17}$ Two of the surveys, "Student Researcher" and "Teaching Support," are particularly useful for gathering data on student and faculty impressions of orientation sessions. The "Student Researcher" survey isolates important affective attitudes, asking the student such questions as "How confident are you in your ability to do archival research?" and "Would you come back to the archives if you had another project that would benefit from the use of its collections?" These questions require the student to explore complex feelings of confidence, trust, and willingness and are designed to help instructors form intelligent strategies to overcome "archival anxiety." However, as Magia Krause points out, self-assessment techniques such as Archival Metrics often risk various forms of bias resulting from word choice, phrasing, or evaluator understanding. ${ }^{18}$ Another drawback of affective surveys is the potential for issues to arise with university IRBs (Institutional Review Boards), which may require a lengthy approval process for any instrument that involves humans as research subjects. Despite these handicaps, Archival Metrics offers a systematic approach for improving archives and special collections instruction based on the expressed needs of researchers.

\section{Learning Assessments: Classroom Assessment Techniques (CATs), Fixed- Choice Tests, and Assignments}

Learning assessments measure cognitive understanding of skills or knowledge through a variety of tools. We describe here three tools that have yielded useful results in information literacy instruction, special collections and archives instruction, or both.

\section{Classroom Assessment Techniques (CATs)}

Classroom Assessment Techniques, or CATs, are formative assessment methods that are applied before or during class sessions, enabling teachers to adjust their approach as needed to ensure that learning objectives are met. This diagnostic, dialogic technique can take many forms, including exercises, worksheets, polls, and other activities. Academic faculty have long relied on CATs to guide their teaching. Information literacy instructors have also embraced CATs because they engage students in active learning and provide them opportunities to immediately practice and receive feedback on what they are learning. The classic one-minute paper, in which students write short answers about assigned topics for one minute only, is among the most popular ILI assessment tools. ${ }^{19}$ Carolyn Radcliff relates

17. "Archival Metrics: Promoting a Culture of Assessment in Archives and Special Collections," a joint project of the University of Michigan, the University of North Carolina-Chapel Hill, and the University of Toronto, available online at www.archivalmetrics.org.

18. Magia Krause, "Undergraduates in the Archives: Using an Assessment Rubric to Measure Learning," The American Archivist 73, no. 2 (2010): 511.

19. Elizabeth Choinski and Michelle Emanuel, "The One-Minute Paper and the One-Hour Class: Outcomes Assessment for One-Shot Library Instruction,” Reference Services Review 34, no. 1 (2006): 148-55. 
several other examples of CATs commonly used in the ILI environment, including a "defining features" matrix (which asks students to demonstrate knowledge of the differences between concepts or resources) and directed paraphrasing (in which students translate concepts learned into their own words). Because of their specificity, CATs can be limited in scope and thus limited in results; however, they are valued in both campus and ILI classrooms for their brevity, adaptablity, and easy yield of results.

Because CATs are by nature active learning exercises, they have worked well in the hands-on learning environment of special collections and archives classrooms. In one case study, Ryan Bean and Linnea M. Anderson gave a new spin to the traditional document analysis worksheet, a favorite standby because it so easily engages students with primary source materials and promotes critical thinking. ${ }^{20}$ For a hands-on exercise with primary sources for a "How to do History" special collections experience, Bean and Anderson grouped sources into collections and asked students to analyze the collection using a collection analysis worksheet that asked questions like, "For what audience or purpose do you think these items were created? Is there a bias?" ${ }^{21}$ When students shared their responses in a discussion following the exercise, Bean and Anderson checked understanding of the concepts they had introduced and posed further questions that led students to discover that each collection only told part of a larger story. This modification encouraged deeper learning and fuller understanding of perspective, narrative, and interpretation. In planning the primary source modules, the authors took cues from and tied their efforts to broader library and campuswide initiatives emphasizing information literacy, including student-learning outcomes. Tying their approach to the larger institutional efforts ensured that the time and effort spent planning and executing the modules would be seen as time well spent in meeting larger campus goals for information literacy. ${ }^{22}$

There are numerous other exciting examples in the literature documenting handson exercises in the special collections classroom, but unfortunately, for the purposes of this article, the majority gloss over or leave out entirely a discussion of the assessment component of the exercise. This may be because special collections librarians and archivists have been more concerned with reporting on the organizational aspects of instructional outreach, such as effective faculty collaboration and selection of materials. Or perhaps many of us are working from a more instinctual

20. Ryan Bean and Linnea M. Anderson, "Teaching Research and Learning Skills with Primary Sources: Three Modules," in Past or Portal? Enhancing Undergraduate Learning through Special Collections and Archives, eds. Eleanor Mitchell, Peggy Seiden, and Suzy Taraba (Chicago: Association of College and Research Libraries, 2012), 158-59.

21. Bean and Anderson, "Teaching Research and Learning Skills," 160.

22. Bean and Anderson, "Teaching Research and Learning Skills," 159. 
approach to planning outreach sessions and have not yet taken the next step of consciously tying our classroom exercises to measurable learning objectives or discussing them as CATs with our colleagues through our professional literature. Yet better documenting and codifying CATs for the special collections classroom might greatly enhance the quality and impact of our collective instructional efforts.

\section{Fixed-Choice Tests}

Fixed-choice tests, such as pretests and posttests, are another technique used to assess student learning and the effectiveness of library instruction sessions. By tying the tests to the learning objectives, then testing in advance of the session and again at the end of the session, the instructor seeks to measure whether learning objectives were met. ${ }^{23}$ As Andrew Walsh noted in his survey of ILI literature, multiplechoice tests were the most prevalent assessment methods, likely due to the relative ease and practicality of administering and scoring them. ${ }^{24}$ Joanna Burkhardt used a pretest and posttest tool to assess student learning in a full-credit information literacy course at the University of Rhode Island. Her findings showed that student library skills did improve as a result of the course. She regarded her study as an informative "first-pass analysis of learning outcomes" and useful for helping the instructors to understand which elements of the class could be improved..$^{25} \mathrm{~A}$ major drawback, however, proved to be the amount of time required to analyze the results. As Oakleaf and others have pointed out, fixed-choice tests have significant limitations. ${ }^{26}$ Although they can be made highly reliable and are useful for their ability to gather a lot of data, they tend to measure recognition rather than recall and are not suited to testing higher-level cognitive skills like critical thinking and evaluation. Fixed-choice tests, especially pretests and posttests, reward guessing and run the risk of inducing learners to give answers they think are right rather than testing what they actually know.

Despite the popularity of the format in ILI and broader educational environments, we found scant evidence of pretest and posttest or any other fixed-choice testing in the special collections and archives literature. From this we can surmise that it is not a particularly popular technique for our environment, though it might be worth considering how it could be used to assess the overall effectiveness of semester-long courses, such as the Rhode Island case, or as part of more comprehensive

23. For an exemplary model of fixed-choice tests for information literacy skills, see Project SAILS, which offers a standardized fixed-choice test on its website: https://www.projectsails.org/.

24. Andrew Walsh, "Information Literacy Assessment: Where Do We Start?" Journal of Librarianship and Information Science 41, no. 1 (Mar. 2009): 19-28.

25. Joanna Burkhardt, "Assessing Library Skills: A First Step to Information Literacy," portal: Libraries and the Academy 7, no. 1 (Jan. 2007): 44.

26. Megan Oakleaf, "Dangers and Opportunities: A Conceptual Map of Information Literacy Assessment Approaches," portal: Libraries and the Academy 8, no. 3 (July 2008): 233-53. 
assessment plan, as discussed in the Blended Approach section below. Grassian and Kaplowitz also point out that pretests and posttests need not be fixed-choice, but rather can collect data in words or numbers. ${ }^{27}$ Using this technique in a special collections environment - for example, asking students to write a short paragraph about how they would locate a primary source both before and after a class on the topic-would do much to illustrate the impact of instruction.

\section{Out-of-Class AssignMENTs}

Out-of-class assignments can be an effective approach to overcome the drawbacks of fixed-choice tests. A thoughtfully designed assignment may require more than guessing and thus may assess students' abilities to apply critical thinking skills as they analyze and process the lessons presented during the instructional sessions. Just as faculty members use out-of-class assignments to gauge student progress and learning, so may librarians and archivists employ this technique. Especially given our typically short exposure to students in instructional sessions, an out-of-class assignment emerges as an appealing option. ILI literature as well as special collections and archives literature offers examples of out-of-class assignments to assess student learning. ${ }^{28}$ Sara Beutter Manus describes an embedded music librarian's efforts to improve ILI to an undergraduate music survey course at Vanderbilt's Blair School of Music. ${ }^{29}$ Beutter Manus created a series of information literacy assignments tied to the two research papers for the course, while the professor made sure the students took the assignments seriously by making them part of the course grade. Two of the assignments asked students to "test drive" library resources in a semistructured way. The third required students to keep a research journal, documenting the key phases of the research process throughout the semester, with a final entry devoted to self-reflection. The first two assignments thus assessed the extent of understanding and allowed for timely feedback from the instructor and librarian leading up to the larger research paper assignments. The research journal enabled assessment of how well students incorporated what they learned from library sessions into their research papers, getting at the "Can they do it?" question associated with authentic performance assessments (see below). Beutter Manus noted, however, the extensive time required for grading as a drawback to this approach.

27. Esther Grassian and Joan Kaplowitz, Information Literacy Instruction: Theory and Practice, 2nd ed. (New York: Neal Schuman, 2009), 207.

28. For further discussion of this topic, see Carol Perruso Brown and Barbara Kingsley-Wilson, "Assessing Organically: Turning an Assignment into an Assessment," Reference Services Review 8, no. 4 (2010): 536-56.

29. Sara J. Beutter Manus, "Librarian in the Classroom: An Embedded Approach to Music Information Literacy for First-Year Undergraduates," Notes: Quarterly Journal of the Music Library Association 66, no. 2 (Dec. 2009): 249-61. 
Although the special collections and archives literature does not yet include studies on the success of assignments as assessment techniques that are as thorough as this example, there is evidence that out-of-class assignments are being used to assess student learning in our environment as well. ${ }^{30}$ In her case-study contribution to Past or Portal, Julie Grob described her use of a take-home quiz to check student learning after a capstone medieval history class visit to special collections. ${ }^{31}$ The quiz was brief, with both multiple-choice and short-answer elements. The first five questions checked student learning, while a final short-answer question offered students the chance to evaluate the session by asking, "Is there anything related to manuscripts you would have liked to learn more about during the class visit?" As with other types of assessment, assignments need to be carefully crafted to align with learning objectives and be most effective; thus, they do take time to create. Grob's example of a largely fixed-choice assignment has the advantages of being relatively easy to develop and grade; furthermore, it is valuable because it includes both reaction and learning assessment methodologies in a single, brief instrument.

Although assignments, fixed-choice tests, and CATs are seen by many as essential to the learning process within the classroom, one longstanding criticism of all three types of learning assessments is that they are artificial constructs. While useful for determining whether or not students "get it," they do not measure whether students can successfully apply this knowledge in real-life situations. To judge that kind of impact, we must turn to authentic performance assessments.

\section{Performance Assessments: Citation Analysis, Rubrics, and Observational Assessment}

\section{Citation Analysis}

Citation analysis is the most popular example of performance assessment. It involves examining the number and sometimes the quality of sources cited in students' final course papers or research projects. If students appropriately cite relevant references in their papers, it may be an indication that a librarian-led

30. Shedlock, Sims, and Kubilius refer to the use of assignments to assess learning, but they do not provide details of these assignments in their article. James Shedlock, Ronald H. Sims, and Ramune K. Kubilius, "Promoting Teaching in the History of Medicine in a Medical Curriculum," Journal of the Medical Library Association 100, no. 2 (Apr. 2012): 138-41. Losoff, Sinkinson, and Newsom describe a desire to add an out-of-class assignment to the next iteration of instructional sessions they conduct with undergraduate science classes. Barbara Losoff, Caroline Sinkinson, and Elizabeth Newsom, "Special Collections Instruction in the Sciences: A Collaborative Model," in Past or Portal? Enhancing Undergraduate Learning through Special Collections and Archives, eds. Eleanor Mitchell, Peggy Seiden, and Suzy Taraba (Chicago: Association of College and Research Libraries, 2012), 137-44.

31. Julie Grob, "More than Gold Leaf: Teaching Undergraduates in Capstone Courses about the Scholarly Use of Medieval Manuscripts," in Past or Portal? Enhancing Undergraduate Learning through Special Collections and Archives, eds. Eleanor Mitchell, Peggy Seiden, and Suzy Taraba (Chicago: Association of College and Research Libraries, 2012), 145-50. 
instructional session contributed to their ability to locate and interpret appropriate sources.

The literature on citation analysis for information literacy instruction is extensive, yet an intriguing study conducted recently describes a new approach to the technique. ${ }^{32}$ Chris Leeder, Karen Markey, and Elizabeth Yakel created and tested a faceted taxonomy with the idea that it could be used as a standardized tool assessing quality of student bibliographies. ${ }^{33}$ The taxonomy was used to test the impact of a social media game called BiblioBouts on the general quality of student work as exhibited by their research bibliographies. ${ }^{34}$ The BiblioBouts project is an online, social-learning game that students play while they are completing their research paper assignments. Students compete with one another in a series of "bouts" aligned with the various steps of the research process, ending with a research bibliography. The authors applied their faceted taxonomy to the students' bibliographies, comparing the work of students who participated in the game against a control group of nonplayers. The results of this multilayered study suggest that this type of game may improve the quality of students' bibliographies. The authors further found that the faceted taxonomy was useful in allowing for a granular analysis of the quality of student bibliographies as a reflection of their understanding of the research process and has potential for use as a standardized tool to that end. Although the game as it was developed is not directly applicable to special collections, and the findings of the study bear further research, it is interesting to consider that social-learning games may have a positive impact on student learning and that a standardized tool for measuring the quality of student bibliographies may be able to help us measure this type of learning efficiently and effectively.

The literature includes some examples of student citation analysis by special collections librarians. For example, Michelle McCoy describes a multiyear review of

32. For more on citation analysis, see in particular: Beth A. Mohler, "Citation Analysis as an Assessment Tool," Science and Technology Libraries 25, no. 4 (2005): 57-64; Stacey Knight-Davis and Jan S. Sung, "Analysis of Citations in Undergraduate Papers," College \& Research Libraries 69, no. 5 (Sept. 2008): 447-58; and Anne Middleton, "An Attempt to Quantify the Quality of Student Bibliographies," Performance Measurement and Metrics 6, no. 1 (2005): 7-18.

33. Chris Leeder, Karen Markey, and Elizabeth Yakel, "A Faceted Taxonomy for Rating Student Bibliographies in an Online Information Literacy Game," College and Research Libraries 73, no. 2 (Mar. 2012): 115-33.

34. The "Evaluation Plan" on the BiblioBouts website describes the taxonomy as follows: "The project team compares the bibliographic citations in the graded papers written by students who did and did not play the game. To rate the citations, team members have developed the Faceted Taxonomy for Classifying Citations to Digital Information that features these 5 facets: (1) information format, (2) literary content, (3) author identity, (4) editorial process, and (5) publication purpose. Within each facet are listed 6 to 24 categories that describe the citation in hand. For example, some of the 24 categories in the Information Format facet are blog, policy statement, consumer magazine, encyclopedia, monograph, and scholarly journal." See http:// bibliobouts.si.umich.edu/BiblioBoutsEvalPlan.html. 
students' final papers for a semester-long class built around the use of a particular manuscript collection at DePaul University. ${ }^{35}$ Students were asked to include a self-assessment in their final papers, and the majority of students expressed positive reactions to the special collections experience. Library staff reviewed these responses alongside the students' citation lists to measure the extent to which special collection sources were actively incorporated into their papers. After noting some discrepancies between how useful students said the primary sources were to their research and the number and types of sources actually cited by students, adjustments were made to the course. McCoy observed a steady increase in the average number of archives sources used from year to year and attributed this result to the ways that the course instructor and librarian revised their presentations on using primary sources. McCoy also suggested that the increase in citations of archival materials from year to year might also be due to the further processing of the collection during the period studied, which resulted in better and more detailed descriptions of the materials it contained. Improved collection access might therefore have also played a role in improving collection usage and citation.

Citation analysis is a useful form of assessment in that it can show the extent to which students use original sources from special collections in their research projects. However, one can argue that it is difficult to determine a direct relationship between the instruction session and the use of the sources in the paper. Could the student have instead found the sources independently, or could a conversation with a reference librarian, faculty member, or fellow student have resulted in the discovery and use of the sources? Furthermore, examining a bibliography or works-cited list without the full context of the paper does not indicate how the sources were used or how well students synthesized their source analyses into the arguments of their papers. Thomas Reinsfelder has discussed the use of citation analysis to measure the impact of one-on-one research consultations with librarians on the quality of citations in undergraduate papers. In his study, Reinsfelder showed that citations of students who met with librarians scored higher in terms of quality, authority, and dates for their citations than those of students who did not. His study also indicated that, while meeting with a librarian might improve overall quality of citations, such improvement does not necessarily lead to a higher grade. ${ }^{36}$ It is thus important to regard the impact of instruction sessions on student citations as an indicator of successful interactions with students within a larger context.

Analyzing citations is most meaningful when clear learning objectives are established. If merely locating an original source in special collections is a learning

35. Michelle McCoy, "The Manuscript as Question: Teaching Primary Sources in the Archives: The China Missions Project," College and Research Libraries 71, no. 1 (Jan. 2010): 49-62.

36. Thomas L. Reinsfelder, "Citation Analysis as a Tool to Measure the Impact of Individual Research Consultations," College and Research Libraries 72, no. 2 (May 2012): 263-77. 
objective of the assignment, then citing a source in a paper is an indication that the student learned that particular skill. If the learning objective is that students should thoroughly analyze such a source and use it to demonstrate understanding of particular issues or topical understanding, a citation list is naturally not enough. As with any assessment model, a clear understanding of what is being measured, and why, must be developed for the practice to become meaningful and effective.

\section{RUBRICS}

Scoring rubrics, a traditional component of $\mathrm{K}-12$ learning assessment, are becoming more common among ILI librarians. ${ }^{37}$ Rubrics measure student output in the form of products, results, or responses against specific, precisely worded criteria. Rubrics set performance standards or proficiency levels in clear, objective language and assign each standard or level a score. Scores are then totaled and compared across the tested group. Rubrics are most commonly used with authentic assessments, such as papers, portfolios, or exhibits, which measure the direct application of skills learned. ILI librarians have found rubrics to be particularly useful because of their flexibility. They can be easily adapted to the ACRL Information Literacy Competency Standards or other standards developed to measure a wide range of skills, including varying levels of detail. They can also be tailored to a wide variety of instructional contexts, including special collections and archives. ${ }^{38}$ Rubrics promote grading consistency, which can be a challenge with other types of authentic assessments. Carolyn Radcliff et al. point out that the rubric can be more than just a grading scale; indeed, it can be a vital tool in the learning process if students are made aware of it before completing the assignment. ${ }^{39}$ For example, Lorrie Knight developed a rubric to gauge information literacy aptitudes as demonstrated in student bibliographies. After levels of achievement were defined in the rubric for each learning objective, these were shared with students before they completed the project. Analysis of their work after completion revealed important gaps in the lessons being taught to students, which could then be corrected in future iterations of the class. ${ }^{40}$

Rubrics have also been used successfully in special collections and archives environments. Magia Krause used a rubric to assess student performance on a document

37. See the RAILS project website for numerous examples of rubrics used to assess information literacy learning: www.railsontrack.info.

38. Meg Meiman, Coordinator of the Undergraduate Research Program at the University of Delaware, is adapting rubrics from the Association of American Colleges and Universities VALUE Rubrics to special collections environments. See the AAC\&U website for example rubrics available for adaptation: www.aacu.org/value/rubrics/index.cfm. Meg Meiman, e-mail message to authors, June 22, 2012.

39. Carolyn Radcliff et al., A Practical Guide to Information Literacy Assessment for Academic Librarians (Westport, Conn.: Libraries Unlimited, 2007), 128.

40. Lorrie A. Knight, "Using Rubrics to Assess Information Literacy," Reference Services Review 34, no. 1 (2006): 43-55. 


\begin{tabular}{|c|c|c|c|c|}
\hline Criteria & Minimal & Fair & Good & Exemplary \\
\hline & $I^{*}$ & 2 & 3 & 4 \\
\hline Observation & $\begin{array}{l}\text { Makes a very brief } \\
\text { or erroneous } \\
\text { attempt at identify- } \\
\text { ing the basic char- } \\
\text { acteristics of the } \\
\text { sources. }{ }^{\text {tok }}\end{array}$ & $\begin{array}{l}\text { Offers only a basic } \\
\text { description of the } \\
\text { sources and may } \\
\text { include errors. }\end{array}$ & $\begin{array}{l}\text { Describes most of } \\
\text { the elements of } \\
\text { the sources cor- } \\
\text { rectly. }\end{array}$ & $\begin{array}{l}\text { Thoroughly and } \\
\text { accurately } \\
\text { describes elements } \\
\text { of document, pho- } \\
\text { tograph, and find- } \\
\text { ing aid. }\end{array}$ \\
\hline $\begin{array}{l}\text { Interpretation/ } \\
\text { Historical Context }\end{array}$ & $\begin{array}{l}\text { Is not able to place } \\
\text { any of the sources } \\
\text { in a broader his- } \\
\text { torical context. }\end{array}$ & $\begin{array}{l}\text { Offers I example } \\
\text { in which a source } \\
\text { is placed in a } \\
\text { broader historical } \\
\text { context. }\end{array}$ & $\begin{array}{l}\text { Explains and gives } \\
\text { examples of the } \\
\text { meaning and use- } \\
\text { fulness of more } \\
\text { than Ibut not all of } \\
\text { the sources, plac- } \\
\text { ing them in a } \\
\text { broader historical } \\
\text { context. }\end{array}$ & $\begin{array}{l}\text { Explains and gives } \\
\text { examples of the } \\
\text { meaning and use- } \\
\text { fulness of all of the } \\
\text { sources and places } \\
\text { them within a } \\
\text { broad historical } \\
\text { context. }\end{array}$ \\
\hline $\begin{array}{l}\text { Evaluation/ } \\
\text { Critical Thinking }\end{array}$ & $\begin{array}{l}\text { Does not offer any } \\
\text { additional informa- } \\
\text { tion about the } \\
\text { source besides } \\
\text { what is already } \\
\text { provided. }\end{array}$ & $\begin{array}{l}\text { Asks questions } \\
\text { about I source } \\
\text { regarding its valid- } \\
\text { ity, limitations, and } \\
\text { strengths }\end{array}$ & $\begin{array}{l}\text { Able to ask ques- } \\
\text { tions about more } \\
\text { than I but not all } \\
\text { of the sources } \\
\text { regarding their } \\
\text { validity, limitations, } \\
\text { and strengths. }\end{array}$ & $\begin{array}{l}\text { Able to ask ques- } \\
\text { tions about all of } \\
\text { the sources } \\
\text { regarding their } \\
\text { validity, limitations, } \\
\text { and strengths. }\end{array}$ \\
\hline Research Skills & $\begin{array}{l}\text { Shows no aware- } \\
\text { ness of how to find } \\
\text { additional } \\
\text { resources. Does } \\
\text { not mention } \\
\text { archives at all and } \\
\text { is unable to come } \\
\text { up with new } \\
\text { research questions } \\
\text { based on the } \\
\text { sources. }\end{array}$ & $\begin{array}{l}\text { Demonstrates lim- } \\
\text { ited knowledge of } \\
\text { where to go for } \\
\text { additional } \\
\text { resources. Does } \\
\text { not mention } \\
\text { archives in a mean- } \\
\text { ingful way. Shows } \\
\text { limited ability to } \\
\text { ask new research } \\
\text { questions based on } \\
\text { the sources. }\end{array}$ & $\begin{array}{l}\text { Shows some } \\
\text { awareness of addi- } \\
\text { tional sources, } \\
\text { both primary and } \\
\text { secondary. } \\
\text { Mentions archives } \\
\text { in a meaningful } \\
\text { way. Demonstrates } \\
\text { some ability to ask } \\
\text { new research } \\
\text { questions based on } \\
\text { the sources. }\end{array}$ & $\begin{array}{l}\text { Exhibits ability to } \\
\text { ask new research } \\
\text { questions based on } \\
\text { the sources and to } \\
\text { recognize the } \\
\text { existence of addi- } \\
\text { tional resources, } \\
\text { both primary and } \\
\text { secondary. Exhibits } \\
\text { a meaningful } \\
\text { awareness of } \\
\text { archives and how } \\
\text { to read a finding } \\
\text { aid. }\end{array}$ \\
\hline
\end{tabular}

*All answers received at least I point even if they were blank or erroneous.

wok In this rubric "sources" refers to the document, photograph, and finding aid in the document analysis exercise.

\section{FIGURE 1: Analytic Rubric for Document Analysis, from Magia Krause ${ }^{41}$}

analysis exercise in four categories: document observation, interpretation/historical context, evaluation/critical thinking, and research skills. Krause noted that, when using a rubric, it is important to correlate it exactly with the exercise measured. In her study, the research skills area was consistently low, perhaps because this area was not effectively gauged by a document analysis exercise. Although she noted that rubrics are time-consuming to develop, Krause also commented on the great potential of rubrics to enhance communication and understanding of our instructional goals to faculty members and others by showing exactly what we aim to teach. She also pointed out that rubrics have the potential to increase instructional collaboration among archivists and with teaching faculty. ${ }^{42}$ This strikes us as

41. Krause, "Undergraduates in the Archives," 534.

42. Krause, "Undergraduates in the Archives," 507-34. 
a powerful idea: having a shared set of customizable rubrics for various authentic assignments (for example, a citation analysis rubric, or student-produced exhibit rubric) could lead to significant collaborations and sharing of other instructional content used in special collections and archives settings. Rubrics also have great potential for converting qualitative data into quantitative data within special collections environments. For instance, responses gathered from focus groups or interviews can be converted to a simple set of basic indicators with relative ease, as long as the criteria are clearly and precisely defined.

\section{Observational Assessment}

With an observational assessment method, instructors observe and record student successes and failures as they attempt to perform targeted skills. This technique can be applied during the instructional session or outside it and can yield important evidence about whether students can actually execute what they have learned and insights into why they succeed or fail. As part of her year-long personal assessment portfolio, Avril Cunningham used an observational assessment tool developed by library instruction expert Jennifer Nutefall at George Washington University. ${ }^{43}$ This tool assists instructors in documenting student performance by prompting them to analyze the questions asked by students during class. This information enables instructors to deduce where teaching successes or failures are occurring. The observational assessment tool also includes a "practice time" component, during which the instructor observes students performing a learned skill and taking note of not only how well students succeed or whether they fail but also the steps they follow to complete the tasks, any problems encountered, and workarounds they might devise. Instructors can use the information gathered to refine their teaching.

A very popular form of observational assessment in the ILI literature is librarian participation in course discussions via course management software such as Blackboard. Following the student discussion in such a way allows librarians to catch any ongoing misperceptions related to information literacy and to correct or guide understanding with feedback through the course management system. Insights gained from tracking these misperceptions over time can be used to improve the course syllabus, lessons, and activities. ${ }^{44}$

Observational assessment has great potential in special collections and archives environments. In an undergraduate research seminar at the University of Pennsylvania,

\footnotetext{
43. Avril Cunningham, "Using 'Ready to Go' Assessment Tools to Create a Year Long Assessment Portfolio and Improve Instruction," College and Undergraduate Libraries 13, no. 2 (2006): 75-90.

44. For an overview of librarian participation in online course discussion, see: Pamela Jackson, "Integrating Information Literacy into Blackboard: Building Campus Partnerships for Successful Student Learning," Journal of Academic Librarianship 33, no. 4 (July 2007): 454-61.
} 
the professor recorded the course's final roundtable discussion to understand how undergraduates learn from and use special collections materials. By videorecording the session and publishing excerpts of the transcripts, this observational assessment was transformed from an informal yet valuable course evaluation into a more formalized and demonstrable success story about the positive impact of special collections on student learning. ${ }^{45}$ Although observational assessment, like other methods, can be time consuming and require significant staff resources, the evidence that it yields can shape powerful arguments about the efficacy of teaching with original materials.

\section{A Blended Approach}

The decision to choose one approach to assessment over another will depend on the goals for assessment in a particular situation as well as practical considerations such as time, any direct costs and resources available to cover them, available staff time and expertise, and, importantly, the interests of stakeholders to whom the results will be reported. Each approach has its merits and limitations, and each represents only one piece of the larger learning puzzle. The scope can be expanded, however, by combining techniques. A recurring theme in the literature is that the best assessments are multifaceted. For example, Corey Johnson et al. took the impressive approach of creating a comprehensive suite of techniques for assessing an honors college science fundamentals course, including examples that assess student reaction, learning, and performance. The course was designed collaboratively, with input from the teaching faculty, the librarian, and a learning design consultant, with the goal of incorporating information literacy into the course plan. Their approach involved scaffolded instruction and mixed assessment methods, including student perception surveys, pretesting and posttesting, performance-based assignments, following and participating in online student discussions, exam questions that tested information literacy concepts, and analysis of students' citation lists for their final research project. ${ }^{46}$ While few of us may have opportunities to develop courses in deep collaboration with faculty and instructional design consultants, Johnson's study provides a rationale for becoming more involved in the course design process. The study results also suggested that using multiple, complementary measures provided better and more comprehensive insights than assessments based on a single methodology. Timely assessment of student learning led to slight adjustments throughout the course of the semester, while a postcourse survey indicated that their integrated and collaborative approach to information literacy led to successful learning outcomes.

45. Toni Bowers, "Crazy for Pamela in the Rare Books Library: Undergraduates Reflect on Doing Original Research in Special Collections," in Past or Portal? Enhancing Undergraduate Learning through Special Collections and Archives, eds. Eleanor Mitchell, Peggy Seiden, and Suzy Taraba (Chicago: Association of College and Research Libraries, 2012), 53-70.

46. Corey M. Johnson et al., "Information Literacy Instruction and Assessment in an Honors College Science Fundamentals Course," College and Research Libraries 72, no. 6 (Nov. 2011): 533-47. 
Special-collections librarians have also employed a blended approach to assessment. Librarian Julie Grob and English professor David Mazella together crafted an undergraduate course on the year 1771, integrating a variety of assessment tools and using both in-class exercises and out-of-class assignments in the course to great effect. ${ }^{47}$ As students worked with special collections materials to contextualize course content, Grob also taught the class research skills needed for their assignments and final paper. Each of the class visits to special collections included an inquiry-driven in-class exercise, which was followed by a jointly graded, focused assignment based both on the materials used for the visit and the research skills taught. Specifically, assignments included follow-up research on primary sources using scholarly databases as well as written reports and essays. Over the course term, these assignments became increasingly complex, as they were designed to build upon the skills previously learned. Although the authors did not detail how the assignments were developed to match specific learning objectives, they did observe that the quality of student work on all assignments was notably higher than for courses that did not include such an intensive library component; and they considered that the incorporation of graded assignments based on library research skills contributed greatly to student investment in the material and their learning processes and outcomes.

\section{Looking Forward}

While some instructors in this literature review did use online polling sites (such as SurveyMonkey) for surveys, questionnaires, and quizzes, the review on the whole did not show use of any specialized data-gathering or analysis tools, nor did they note any limitations on assessment due to the lack of such tools. Despite this, there are clear indications that new technologies can offer many potential enhancements of assessments for special collections and archives instruction. ${ }^{48}$ The evolution of integrated request tracking and circulation systems such as Aeon ${ }^{49}$ have the potential to seamlessly connect department operations and users, as long as user privacy is maintained. Such systems might offer methods to link specific class sessions to their registered participants and then quantitatively track participant collection usage, research time, or other useful data. Instructors could couple this information with citation analyses, observational analyses, or even rubrics to enhance or

\footnotetext{
47. David Mazella and Julie Grob, "Collaborations Between Faculty and Special Collections Librarians in Inquiry-Driven Classes," portal: Libraries and the Academy 11, no. 1 (Jan. 2011): 465-87.

48. A new product from Springshare called LibAnalytics may be worth keeping an eye on. The product web page suggests that it may be used to track instruction statistics: https: / / www.springshare.com/ libanalytics/uses.html. For an overview of the product that does not explicitly discuss instruction, see Ellie Dworak, "LibAnalytics," The Charleston Advisor 13, no. 2 (Oct. 2011): 41-44. Michelle Jacobs-Lustig of Pepperdine University gave a presentation about the product at the Southern California Instruction Librarians annual meeting in 2012. A description of her presentation, but not her slides, is available online at www.carl-acrl.org/ig/scil/scilworks/2012/index.html. The University of Kentucky Libraries are also early adopters, as noted, but have not yet discussed the product in detail on their blog, which is available online at http://klibrariesbirdseye.blogspot.com/2012_05_01_archive.html.

49. Atlas Systems, Aeon, www.atlas-sys.com/aeon/.
} 
add new dimensions to those assessments. If such systems were to include survey or testing features, such as automatically e-mailing students who participate in a library instructional activity a questionnaire or quiz after their session, we would, for example, have the opportunity to measure students' reactions or aptitudes by gathering and processing feedback with less time and effort. Integrated assessment systems could also offer the opportunity to combine and connect quantitative with qualitative data, thus presenting over time a richer picture of user experience and collection usage that might reveal potential cause-and-effect relationships and help us to assess impact more successfully at the instructional program level.

Exciting possibilities for learning assessment are also emerging with other new technologies. Online games and tutorials offer unique potential to measure archival intelligence and artifactual literacy learning objectives outside the classroom, and some institutions have begun exploring the possibility of learning assessment through mobile devices. ${ }^{50}$ Audience response technologies, like handheld clicker devices, are designed to gather student responses at various points during an instructional session to help instructors evaluate and adjust their presentations during the session itself. Although we are not aware of any cases where such devices have been used during a special collections instructional session, it seems to us that they easily could be adapted to the physical and security infrastructures of special collections classrooms. Designing tables that have touch screens or tablets built into center consoles that are large enough to also display collections materials would allow for more powerful in-class learning assessment without cluttering work areas and increasing the risk of damaging materials. Just as clickers could be built into the physical infrastructure of special collections classrooms, so, too, could audio or video recording equipment be installed to support observational assessments of class sessions after they take place.

Among the approaches to assessment described above, performance assessment stands out as particularly appropriate to instructional sessions that focus on archival intelligence concepts. If we are trying to teach students how to use a finding aid, how to identify relevant sources, or how to request materials, our efficacy is best measured by asking a behavioral question: "Can they do it?" While we can practice such skills in the classroom through exercises, archival intelligence may be better assessed in the reading room, where we can gauge students' success at the point they must perform and apply what they learned in the classroom. We have been conducting this type of assessment informally for years. Many of us who teach also serve on the reference desk and chat informally with our colleagues about how well students from a class are able to use the collections on their own during sub-

50. Meredith Farkas maintains a bibliography on use of mobile devices in library instruction; see: http:/ / meredithfarkas. wetpaint.com/page/How+to+Enhance+Library+Instruction+with+Mobile+Devices. 
sequent visits. While common in practice, this type of informal assessment is difficult to quantify; we lack a formal way to capture that observational information. Google Analytics and other website visit tracking applications have the potential to observe student performance of archival intelligence concepts, such as how to use a finding aid. Building other capabilities into such systems, such as the ability to ask users whether they are doing research for a class upon landing in the finding aid database, would extend observational assessment possibilities. The integration of user request, circulation tracking, and reference request management systems with finding aid delivery systems would offer still more possibilities. Yet, even without designing or implementing such systems, we can try to maximize the potential of our existing data-gathering systems. For example, including a simple question such as "Is your research related to a class?" on our registration forms can yield much information about who is using our collections, when, and for what purposes.

Performance assessment is also the best way to measure artifactual literacy, but special collections librarians and archivists rarely get the chance to carry out authentic assessments on lessons taught in class sessions that typically last less than an hour. Students most often show that they can interpret and analyze primary sources "in real life" through their course assignments or other products; but, if librarians or archivists are not embedded in the course, they rarely have the opportunity to observe whether artifactual literacy learning is fully demonstrated. As Grob and others have shown, strong relationships with teaching faculty are key to building creative partnerships and can result in significant opportunities for performance assessment. Developing full, for-credit courses taught or co-taught by librarians and archivists in the academic department may hold the best potential for gathering meaningful performance assessment of artifactual literacy concepts and teaching them in the first place. $^{51}$

Although the adaptations described above would do much to advance assessment efforts in our classrooms, they all lack a key element, namely a common and authoritative set of guidelines. The ACRL Information Literacy Competency Standards for Higher Education have long been the foundation for successful teaching in libraries. Although the ACRL standards have received recent critical attention for what they lack (as Robert Schroeder and Ellysa Stern Cahoy point out, the standards address only cognitive competencies and not affective learning indicators such as inquisitiveness, resilience, and persistence), ${ }^{52}$ they have guided an entire movement of

51. An exciting grant-funded project to keep an eye on is the Brooklyn Historical Society "Students and Faculty in the Archives" (SAFA), which seeks to "create a replicable pedagogical model for collaboration between archives and institutions of higher learning," and "will track and evaluate the impact of SAFA participation on key inquiry and archival literacy skills, student engagement, and retention." See http://safa.brooklynhistory.org/.

52. Robert Schroeder and Ellysa Stern Cahoy, "Valuing Information Literacy: Affective Learning and the ACRL Standards," portal: Libraries and the Academy 10, no. 2 (Apr. 2010): 127-46. 
information literacy instruction. Although these standards do include skills related to primary source identification and usage, they do not quite encompass everything taught within special collections and archives environments, at least to the degree of granularity that results in well-defined learning outcomes for our efforts. Trying to fit what we do in our classrooms into the structure of the ACRL standards can often feel like trying to push a square peg into a round hole-they don't quite fit us. Developing a tailored, shared set of "primary source literacy" or "special collections and archives literacy" standards or competencies that are more specific to the skills and concepts that emerge from our classrooms could springboard us into more structured and thus more effective instructional assessment practices. Yakel called for this "new paradigm" nearly a decade ago in 2004, encouraging us to "defin[e] core knowledge and skill sets that would comprise information literacy for primary sources." ${ }^{53}$ Since then, Joanne Archer et al. have advocated for a curriculum to teach primary source literacy. Likewise, Peter Carini echoed Yakel's call for primary source literacy in 2009 , describing the need for "core concepts" that include not only identification and usage of primary sources but also skills based in the physical artifact (such as evaluation of paper quality, handwriting, and dating of documents), as well as contextual and evidential skills. ${ }^{54}$ These concepts, guidelines, and standards have yet to materialize for our profession, though developing them could reap considerable benefits for special collections librarians and archivists. ${ }^{55}$ Not only would we become more pedagogically aligned with our ILI colleagues, but our teaching activities would also become easier to plan and execute.

Whatever the limitations of the ACRL Information Literacy Competency Standards, they gave birth to innumerable learning objectives, activities, exercises, and resulting assessments. From clear guidelines come clear objectives; from clear learning objectives follow imaginative exercises; from imaginative exercises come practical, effective assessments. Establishing thoughtful standards would pave the way for further standardized, customizable assessment tools such as those created by the Archival Metrics Toolkit team, saving instructors countless hours developing such tools on their own. The increased capacity of instructors to derive learning objectives from these recognized standards would open our classrooms to more creative exercises and stimulate the profession into developing a more functional vision of the "primary source laboratory" to which we so often aspire.

53. Elizabeth Yakel, "Information Literacy for Primary Sources: Creating a New Paradigm for Archival Researcher Education," OCLC Systems and Services 20, no. 2 (2004): 63.

54. Joanne Archer, Ann M. Hanlon, and Jennie A. Levine, "Investigating Primary Source Literacy," Journal of Academic Librarianship 35, no. 5 (Sept. 2009): 410-20; Peter Carini, "Archivists as Educators: Integrating Primary Sources into the Curriculum," Journal of Archival Organization 7, no. 1 (2009): 41-50.

55. A significant step in the right direction was a short paper session at the RBMS Preconference in 2012. Peter Carini, Caro Pinto, and Bill Ross presented on curricular concepts, pedagogy, and assessment in special collections. At the time this article was submitted for publications, these presentations were not yet available on the RBMS website: http://rbms.info. 
Beyond these principal benefits, established standards for "primary source" or "special collections and archives" literacy could bring about other secondary, yet substantial advantages to our professional communities. Despite new programs focused on special collections librarianship at UCLA and UIUC, as well as archives tracks in library and information school programs around the country, we lack a way to teach incoming professionals what we practice in our classrooms. Establishing guidelines would give us a strong starting point for this task and point us further toward the goal of diminishing the culture of exclusivity that young special collections professionals face. ${ }^{56}$ Moreover, establishing and promoting such guidelines would continue building the needed bridges between the archives and special collections professions and allow us to define and standardize shared vocabularies for our instructional work. Standards or guidelines for teaching with special collections materials (and the data resulting from assessment activities) might add further legitimacy to our instructional outreach programs and enable us to put "learning closer to the heart of what we do," as Steven Escar Smith has entreated us. ${ }^{57}$ Solid instructional programs could in turn make powerful arguments about both the staff required to offer such programs and the specific competencies they need.

Looking forward, it is vital that instructors in special collections and archives environments communicate about assessment measures as they emerge in their classrooms. By presenting and writing about our instructional experiences in professional venues, including details about assessment measures we have employed (no matter how minimal they might have been), we will promote professional dialogue, build collaborations, and facilitate the continued growth of assessment practices. Sharing our practices, via the literature and possibly a centralized repository of assessment tools, is necessary for the evolution of meaningful instructional assessment. ${ }^{58}$ As we learn of new techniques for assessment from each other, we can begin to craft-and share-comprehensive, integrated assessments of instructional programs in special collections and archives.

Despite the many benefits of effective assessment strategies, designing them is still challenging and time consuming, whether they are related to one-shot class sessions, term-length courses, team-taught sessions, or multiclass modules. This is nothing new, even if we are now more frequently using the language of educational theory to define what we have long understood. What is changing, perhaps, is the motivation and momentum to assess. Special collections and archives profes-

56. Michael Garabedian, "You've Got to be Carefully Taught: American Special Collections Library Education and the Inculcation of Exclusivity," RBM: A Journal of Rare Books, Manuscripts, and Cultural Heritage 7, no. 1 (Mar. 2006): 55-63.

57. Steven Escar Smith, "From 'Treasure Room' to 'School Room': Special Collections and Education," RBM: A Journal of Rare Books, Manuscripts, and Cultural Heritage 7, no. 1 (Mar. 2006): 37.

58. The developers of the Archival Metrics Toolkit are also working on a shared Repository of Archival Metrics (ROAM): http://sils.unc.edu/research/projects. 
sionals are beginning to write about their assessment challenges and successes, and we must continue to expand our dialogue with each other and with colleagues in information literacy instruction, assessment, and administration to ensure that our perspectives and needs contribute meaningfully to ongoing, larger discussions about library contributions to higher education goals.

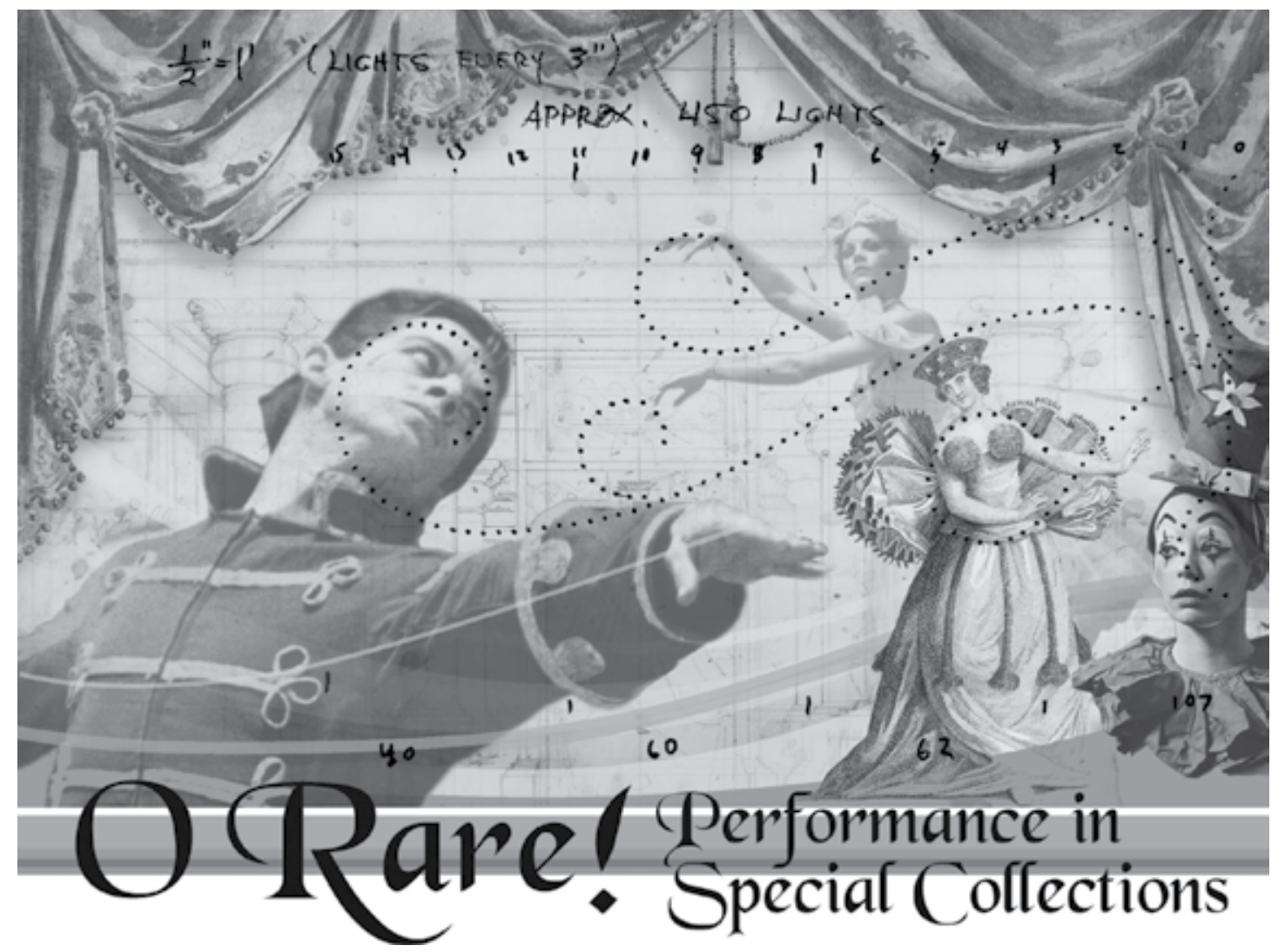

\section{THE 54TH ANNUAL RBMS PRECONFERENCE JUNE $23-26,2013$ | MINNEAPOLIS, MN}

The time has come to talk of many things - of theater, and dance, and musical arts; of laboratories and magic; and why an artifact has a trace; and whether digital facsimiles have wings.

TICKETS ON SALE FEBRUARY 2013

Watch www.rbms.info for details

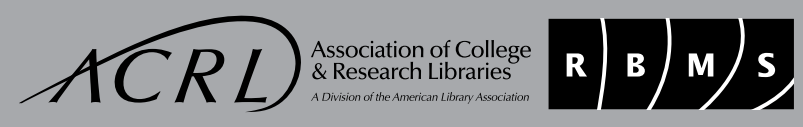

